\title{
ANALYSIS OF EFFECT OF INTERPERSONAL COMMUNICATION ON THE PERFORMANCE OF EMPLOYEES AT FLUID SCIENCES BATAM
}

\author{
$1^{\text {st Nurul Maulina }}$ \\ Departement Of Applied Business \\ Administration \\ Politeknik Negeri Batam \\ Batam, Kepulauan Riau Indonesia \\ Nurulmaulina21@gmail.com
}

\author{
$2^{\text {nd }}$ Maryani Septiana \\ Departement Of Applied Business \\ Administration \\ Politeknik Negeri Batam \\ Batam, Kepulauan Riau Indonesia \\ maryaniseptiana@polibatam.ac.id
}

\begin{abstract}
- interpersonal communication is an important role in employee performance, factors-factors that affect the performance of employees in interpersonal communication becomes an independent variable is self belief, intimacy, interaction management, power of expression, and orientation on others, while the dependent variable is the performance of employees. The research was conducted at PT Fluid Sciences Batam, which is a company engaged in manufacturing namely manufacture of mechanical components for the aerospace industry (Aerospace) located at Jalan Delima Lot 512/513, Industrial Zone Batamindo (BIP), Mukakuning, Batam, This research method is descriptive research, research data retrieval method using a questionnaire, to measure how much influence interpersonal communication on the employee's performance. The data were processed using SPSS program. The analysis showed that three variables of interpersonal communication significantly influence employee performance, while the confidence and power of expression is not significant on teacher performance. Furthermore, adjusted R-square is obtained by 42.9\% influenced by five factors, other $\mathbf{5 7 . 1 \%}$ is konrtribusi of other variables that are not included in this study.
\end{abstract}

Keywords : Interpersonal Communication, self-confidence, familiarity, interaction management, expression power, and orientation to others, and Employee Performance

\section{INTRODUCTION}

\section{A. Background}

Humans are social creatures who have the need and ability to communicate, who need other people and need groups or communities to interact and communicate, interactions that occur between humans are activities carried out repeatedly. This reveals evidence that most people are formed by the results of social integration. Interpersonal communication (interpersonal communication) is communication between someone and other people directly, this affects each participant to capture the reactions of others directly, both verbally and nonverbally [2].

Based on the understanding that has been described previously, it can be concluded that if the creation of mutual understanding on both sides. Intrpersonal communication can be said to be effective or successful. [1] states that there are five things in order to create an effective communication are: Self-confidence, familiarity, interaction management, expression power, and orientation to others, these five things will create an effective interpersonal communication.

As for the human resources have an important role in achieving corporate goals, because human resources role as regulator and driving in any form of activity in the business world. Interpersonal communication is what an employee can put forward the idea of a creative, positive idea, information, as well as complaints to the leadership or colleagues of other employees, and a leader can direct an instruction, motivating, warning and appreciation to the employees, the key to the success of a company is to has qualified human resources with good management and effective form of communication. Therefore, the qualities of interpersonal communication determine the success of a department and have an impact on employee performance improvement.

In addition to effective communication, companies also need to develop resources in order to create a form of performance achieved both in quality and quantity. According [3] the employee's performance is the success rate of an employee in carrying out the tasks and the ability to achieve the goals set. Performance is as a result of what has been done to achieve the target company's employees have been determined. Employee performance will determine the course of events in the company, and the company's success going hand in hand with a good performance and maximum employee.

\section{B. Formulation of the Problem}

The formulation of the problem in this study is to examine the level of influence of interpersonal communication in the dimensions of self-confidence, unity, management interaction, power of expression, and orientation towards others, and performance in the PT Fluid sciences Batam.

\section{Purpose of the Research}

The purpose of this research are to find out how the influence of interpersonal communication in the dimensions of self-confidence, unity, management interaction, power of expression, and orientation towards others, and performance. 


\section{Benefit of the Research}

The benefits of this research are theoretical and practical benefits. Benefits of this research are framework to identifying interpersonal communication to increase staff performance motivation. On the other side, it also give benefit to other parties involved in this research and additional information on interpersonal communication.

\section{LITERATURE REVIEW}

\section{A. Definition of interpersonal communication}

Based [1] is a verbal and nonverbal interaction between two or more, and people who are dependent on each other. Meanwhile, according to Joseph A. [1] in his book states that "Communication is based on the actions performed by a person or more than send and receive messages distorted by interference (noise) in a particular context, and allow for feedback".

Another opinion suggests that interpersonal communication is a process that uses the messages to reach similarity of meaning between-least-between two people in a situation that allows for equal opportunity for the speaker and the listener. Pragmatic model of interpersonal communication, offers five quality interpersonal communication effectiveness According to [1], namely:

1. Confidence (self-confidence)

In interpersonal communication, effective communicators must have the confidence and feel comfortable with other people and in situations of communication in general.

2. Familiarity (immediacy)

Familiarity refers to a merging process between the communicator and the communicant so it will show a similarity between the two.

3. Interaction management (interaction management)

Effective communicators need to control the interaction to achieve the satisfaction of both parties. In building an effective interaction management, no one will feel ignored or felt to be the main character. Each party contributes to the overall communication.

4. Southwestern expression (expressiveness)

Southwestern expression refers to a sincere engagement communicating skills in interpersonal interactions.

5. Orientation on others (other orientation)

Oriented attitude to others is the ability to communicate and interact with others. This orientation also includes communicating the attention and interest in what is being said by the other person.

both parties.

\section{B. Definition of employee performance}

There According [3], employee performance is said to be the success rate of employees in carrying out their duties and the ability to achieve certain goals. This means that employee performance is good and successful if the desired goals can be achieved correctly.
Based on several views about performance, in general performance is the result of work achieved by someone in carrying out the tasks assigned to him with predetermined criteria.

Factors that influence individual performance according to [4]:

i. Factors of ability include (knowledge and skills), talents, interests, and personality factors. Therefore, employees must be employed in jobs that are commensurate with their experience. Gift factors, interests, and personality.

ii. Motivational factors that shape the position of employees in the face of work situations. Motivation is a condition that encourages employees to be directed towards achieving organizational goals (business goals)

\section{Framework}

The description or concept of thinking in this study is as follows:

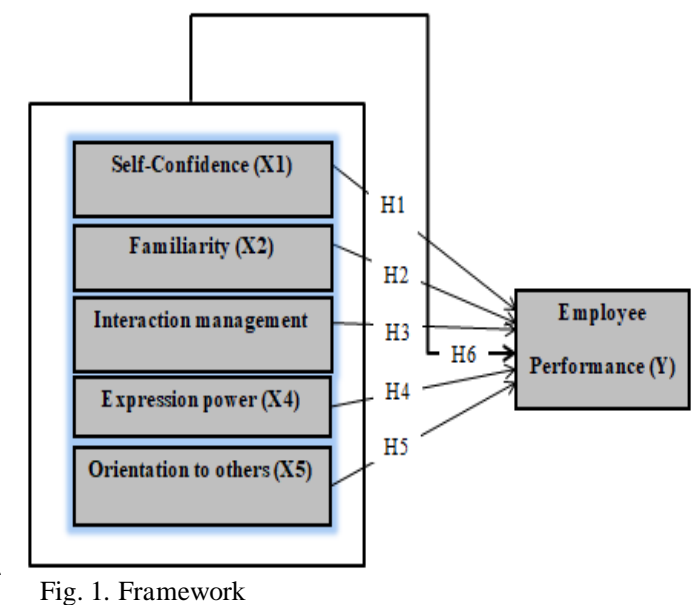

\section{METHODS}

\section{A. Design / Type of Research}

The type of research used in this study is descriptive research. According to [5] descriptive research is a study conducted to test the value of independent variables, regardless of whether one or more variables (independent) are compared or connected with other variables.

\section{B. Population and Samples}

The population in this research is all employees at PT Fluid Sciences Batam with 192 employees. This study uses a purposive sampling model and has 66 respondents, namely with respondents from PT Fluid sciences Batam employees who have worked for two years and above. Respondents are customers who

Samples number using Slovin's formula:

$$
n=\frac{N}{1+N e^{2}}
$$


Information:

$\mathrm{n}=$ Number of samples

$\mathrm{N}=$ Total population

$\mathrm{e}=$ Error rate $=10 \%$

\section{Data collection technique}

To obtain the data needed in order to conduct an analysis of the provisional proof or hypothesis of the problem raised, the data collection techniques carried out in this study are as follows:

a. Questionnaires are data collection techniques carried out by giving a set of questions or written statements to respondents to answer.

b. Observation (observation) is an activity by using the five senses, can be by sight, smell, hearing, to obtain information needed to answer research problems, namely by looking at how the communication patterns that occur in the company.

c. Documentation is available data in the form of letters, diaries, reports, photos, and so on.

\section{Validity and Reliability}

Validity is a measure that shows the level of validity or authenticity of an instrument, a questionnaire is said to be valid if the question on a questionnaire is able to express something that will be measured by the questionnaire. To test the validity can use the formula:

$r x y=\frac{n\left(\sum X Y\right)-\left(\sum X\right)\left(\sum Y\right)}{\sqrt{\left\{n \sum x^{2}-\left(\sum X^{2}\right)^{2}\right\}\left\{n \sum Y^{2}-\left(\sum Y^{2}\right)^{2}\right\}}}$

Information:

$\mathrm{r} x \mathrm{y}=$ Correlation coefficient

$\sum X=$ Number of scores for item $X$

$\sum \mathrm{Y}=$ Total score (all items)

$\mathrm{N}=$ Number of respondents

Reliability or trust test implies whether an instrument can measure something that is measured consistently from time to time. Data is said to be reliable if the value of Cronbach Alpha counts> Cronbach Alfa Table. To states that reliability can be determined using the formula:

Information:

$$
\alpha=\left(\frac{K}{K-1}\right)\left(\frac{1-\sum a b^{2}}{\sigma b^{2}}\right)
$$

$\alpha=$ instrument reliability coefficient (Cronbach)

$\mathrm{K}=$ number of questions

$\Sigma \sigma \mathrm{b}^{2}=$ total item variance

$\Sigma \sigma \mathrm{t}^{2}=$ total variance

\section{E. Data analysis method}

Data analysis method in this study use:

1. Descriptive statistics

Descriptive statistics include the presentation of data through tables, graphs, pie charts, pictograms, measurements of central tendencies including calculation of mean, median, mode, calculation of quartiles, deciles, presentation, calculation of data distribution through calculation of averages and standard deviations, calculation of percentages [6].

2. Inferential

Inferential statistics are techniques or tools used to prove the validity of probability theory used in research in the social sciences. Inferential statistics are statistics used in social research as a tool for analyzing data for explanatory purposes. This model statistic is only used for generalization purposes. In other words, this study aims primarily to test the research hypothesis [6].

a. Classic assumption test

Statistical requirements must be fulfilled in multiple linear regression analysis based on ordinary least square. They are:

1. Test for normality

To check whether our research data is from a population whose distribution is normal.

2. Multicollinearity test

Multicollinearity test is a test used to test whether the regression model found a correlation between independent variables. A good and correct regression model, there should be no correlation between independent variables.

3. Heterocedasticity test

Heterocedasticity test is used to see whether there is an inequality of variance from one residual to another observation. Spearman Rank Test which correlates between absolute residual regression results with all independent variables. If the correlation results are smaller than 0.05 then the regression equation contains heteroscedasticity and vice versa means non heteroscedasticity.

b. Multiple Regression Analysis

This model is a multiple regression model where to know the regression problem of the influence of the work environment on employee performance at PT Fluid Sciences Batam. The multiple linear regression equation model is [5]:

$\mathrm{Y}=\mathrm{a}+\mathrm{b} 1 \mathrm{X} 1+\mathrm{b} 2 \mathrm{X} 2+\mathrm{b} 3 \mathrm{X} 3+\mathrm{b} 4 \mathrm{X} 4+\mathrm{b} 5 \mathrm{X} 5+\mathrm{b} 6 \mathrm{X} 6+\mathrm{e}$

Source: (Sugiyono, 2011)

Information:

$\mathrm{Y}=$ Staff Performance

$\mathrm{X} 1=$ Self-confidence

$\mathrm{X} 2$ = Familiarity

X3 = Interaction Management

X4 = Power of Expression

$\mathrm{X} 5=$ Orientation to others

$\mathrm{X} 6$ = Interpersonal Communication

b1, b2, b3, b4, b5, b6 = Regression Coefficient

$\mathrm{a}=$ Constant

$\mathrm{e}=$ Error (other independent variables besides the regression model)

c. Hypothesis testing

T test (Partial) Partial proof of hypothesis used to determine the effect of each variable, both independent variables on the dependent variable are statistically significant, and Using regression coefficient tests for each variable has an effect on whether the variable is meaningful or not to the variable bound. 


$$
t=r \frac{\sqrt{n-2}}{\sqrt{1-r^{2}}}
$$

Source: (Sugiyono, 2011)

Information:

r: Regression coefficient

$\mathrm{n}$ : number of respondents

\section{RESULT AND DISCUSSION}

\section{A. Results}

The results of this study are grouped into several categories including age, gender, last education, length of work, and department. 1) Based on age, the age of respondents ranged from 20 to more than 39 years. Most respondents were aged 35-39 with a percentage of $43.93 \%$. 2) more sex than men with a frequency of 55 male respondents and 11 female respondents. The percentage for each respondent was $83.33 \%$ for men and $16.66 \%$ for women. 3) Based on the latest education, the highest number of respondents from high school education level was 48 people $(73 \%)$. Then followed by respondents from the D3 education level as many as 7 people (10\%) and none at the D4 education level, and S1 education level is 11 people $(17 \%)$. 4) Based on work for more than 10 years with data as follows: length of work under 10 years as many as 44 people $(66.66 \%)$, the remaining 10 people $(15.15 \%)$ have worked between $8-10$ years, 4 people $(6.06 \%)$ have worked for 5-7 years, 8 people $(12.12 \%)$ have worked for 2-4 years. 5) Based on the position and position most are respondents in the Seals Operator position as many as 24 people $(36.4 \%)$, then Bellows as many as 8 people (12.1\%).

\section{B. Discussion}

The Based on the results of the processing of primary data obtained through questionnaires and statistical analysis processes, several decisions were made about the problems raised and determined as hypotheses. The conclusions obtained are the results of data analysis that has been obtained with a measuring instrument that has proven its validity with the results of the validity test using correlation techniques. With the results of the correlation value (r)> 0.0361 the instrument proved valid. Besides that the instrument has also been measured for its reliability (reliability) which results in a value of $\alpha>0.06$ proving that reliable measuring instruments are used as data collection facilities.

To ensure that the regression line equation obtained is linear and can be used (valid) to look for forecasting, it will be tested the assumption of multicollinearity, heteroscedasticity and normality. Through multicollinearity test, it was produced that there was a perfect relationship between independent variables in the regression with evidence of VIF value $<10$ and tolerance $>0.1$, it can be concluded that there were no symptoms of multicollinearity between independent variables in the regression model.
While the heteroscedasticity test is carried out to test the inequality of the variance of the residuals in the regression model through the Scatterplot chart resulting in points that spread randomly, not forming a certain clear pattern, and spread both above and below the 0 (zero) on the $\mathrm{Y}$ axis, this means that there is no classical assumption of heteroscedasticity in the regression model made, in other words accepting the homoskedasticity hypothesis.

Normality tests are also conducted to test whether in the regression model, the independent variables and the dependent variable are both normally distributed or not. The normality test of data in the study is seen by paying attention to the points on the Normal P-Plot of Regression Standardized Residual of the dependent variable. With the results of the data spreading around the diagonal line and following the direction of the diagonal line, the regression model meets the assumptions of normality.

TABLE I. VARIABLE CHARACTERISTICS

\begin{tabular}{|c|c|c|c|c|}
\hline Variables & Min & Max & Average & $\begin{array}{l}\text { Standard } \\
\text { Deviation }\end{array}$ \\
\hline Confidence & 15,00 & 22,00 & 18,68 & 1,87 \\
\hline Familiarity & 15,00 & 20,00 & 19.35 & 1,09 \\
\hline $\begin{array}{c}\text { Interaction } \\
\text { management }\end{array}$ & 13,00 & 20,00 & 18.95 & 1,41 \\
\hline Expression power & 12,00 & 20,00 & 19,12 & 1,53 \\
\hline Orientation to Others & 17,00 & 20,00 & 19,56 & 0,75 \\
\hline $\begin{array}{c}\text { Employee } \\
\text { performance }\end{array}$ & 13,00 & 21,00 & 19,70 & 1,42 \\
\hline
\end{tabular}

Based on the validity of the test results for all variables, invalid items are as much as three questions so that the total number of questions used in this study were a total of 27 questions:

TABLE II. RELIABILITY TEST RESULTS

\begin{tabular}{|c|c|l|}
\hline Variables & Cronbach's Alpha & Conclusion \\
\hline $\begin{array}{c}\text { Employee } \\
\text { performance }\end{array}$ & 0.823 & Reliable \\
\hline Confidence & 0.722 & Reliable \\
\hline Familiarity & 0.819 & Reliable \\
\hline $\begin{array}{c}\text { Interaction } \\
\text { management }\end{array}$ & 0.775 & Reliable \\
\hline $\begin{array}{c}\text { Expression power } \\
\text { Orientation to } \\
\text { Others }\end{array}$ & 0.867 & Reliable \\
\hline
\end{tabular}

(Source: Primary data are processed, 2019) 
The $F$ test shows $F$ value of 10,783dengan significance level of $0.000(\mathrm{p}<0.05)$. This indicates that confidence, intimacy, interaction management, power of expression, and orientation on others variables collectively have a significant influence on employee performance, or in other words the regression model can be used to predict the performance of employees. F test results can be seen in Table 3 below:

TABLE III. F TEST RESULTS

\begin{tabular}{|l|c|c|c|c|}
\hline Model & F & \multicolumn{2}{|c|}{ Sig. } & Conclusion \\
\hline & Regression & 10.783 & 0,000 & Significant \\
\hline \multicolumn{4}{|l}{} \\
(Source: Primary data are processed, 2019)
\end{tabular}

The t-test was conducted to see the level of significance of each - each independent variable on the dependent variable. The test results can be seen from the significant value contained in Table 4

TABLE IV. T TEST RESULTS

\begin{tabular}{|c|c|c|c|c|}
\hline \multirow{2}{*}{ Model } & \multicolumn{2}{|c|}{ t test } & \multirow{2}{*}{ Sig. } & Conclusion \\
\cline { 2 - 5 } & B & t & & \\
\hline (Constant) & 3,194 & 1.645 & 0,105 & Significant \\
\hline Confidence & 0.168 & 1,258 & .213 & Not significant \\
\hline Familiarity & 0.169 & 2,045 & 0.045 & Significant \\
\hline $\begin{array}{c}\text { manejemen } \\
\text { Interaction }\end{array}$ & 0,242 & 2,320 & 0,024 & Significant \\
\hline \begin{tabular}{c} 
Expression power \\
\hline $\begin{array}{c}\text { Orientation to } \\
\text { Others }\end{array}$
\end{tabular}$-0.147$ & -1.466 & 0.148 & Not significant \\
\hline \\
(Source: Primary data are processed, 2019) & 3.175 & 0,002 & Significant \\
\hline
\end{tabular}

Hypothesis test results the table shows that there is significant influence between Familiarity, Management is interaction, and Orientation On Other People with the employee's performance. Confidence and Power Expression and no significant positive effect, the performance of employees.

TABLE V. TEST RESULT THE COEFFICIENT OF DETERMINED (ADJUSTED R2)

\begin{tabular}{|c|c|c|c|c|}
\hline Model & & $\begin{array}{c}\text { R } \\
\text { Square }\end{array}$ & Adjusted R Square & Std. Error of the Estimate \\
\hline 1 & & & & \\
& 688 & .473 & .429 & 1.37470 \\
\hline
\end{tabular}

(Source: Primary data are processed, 2019)

Based on the results of determining the coefficient of the independent variable, you can explain the effect of employee performance by $43 \%$, and the remainder determined by other variables.

\begin{tabular}{|c|c|c|c|}
\hline \multicolumn{4}{c|}{ TABLE VI } \\
\hline Variabel & Tolerance & VIF & Conclusion \\
\hline $\begin{array}{c}\text { Self- } \\
\text { confidence }\end{array}$ & 0,649 & 1,542 & No Multicollinearity \\
\hline
\end{tabular}

\begin{tabular}{|c|c|c|c|}
\hline Variabel & Tolerance & VIF & Conclusion \\
\hline $\begin{array}{c}\text { Familiarity } \\
\text { Keakraban }\end{array}$ & 0,402 & 1,792 & No Multicollinearity \\
\hline $\begin{array}{c}\text { Interaction } \\
\text { Management }\end{array}$ & 0,412 & 2,425 & No Multicollinearity \\
\hline $\begin{array}{c}\text { Expression } \\
\text { Power }\end{array}$ & 0,393 & 2,542 & No Multicollinearity \\
\hline $\begin{array}{c}\text { Orientation to } \\
\text { Others }\end{array}$ & 0,701 & 1,426 & No Multicollinearity \\
\hline
\end{tabular}

(Source: Primary data are processed, 2019)

The test results in the table, Self-confidence has a coefficient of 0.213 at a significance level of 0.000 , (p> 0.05 ), meaning that there is no significant effect between self-confidence and employee performance in accordance with the hypothesis that there is a significant influence between self-confidence and employee performance. Familiarity has a coefficient of 0.045 at a significance level of 0.000. ( $p<0.05$ ), meaning that there is a significant influence between familiarity with employee performance. Interaction Management has a coefficient of 0.024 at a significance level of 0,000 . ( $\mathrm{p}<0.05)$, meaning that there is a significant influence between Management Interaction on employee performance. Power Expression has a coefficient of 0.148 at a significance level of 0,000 . (p>0.05), meaning that there is no significant influence between the power of expression on employee performance. Orientation on others has a coefficient of 0.002 at a significance level of 0,000 . ( $p$ $<0.05$ ), meaning that there is a significant influence between orientation on others on employee performance.

\section{CONCLUSIONS AND SUGGESTIONS}

\section{A. Conclusions}

Based on the discussion that has been described, it can be concluded that there are significant between Interpersonal Communication and employee performance. The test results also show that there is positive but not significant between Confidence and Power Expression on employee performance. Further proving that there is influence between interpersonal communication and employee performance results are consistent with the hypothesis. From the discussion that has been described, then conclusions can be drawn as follows:

a. The results of hypothesis testing (1) have proven that there is a significant influence between self-confidence and employee performance.

b. The results of hypothesis testing (2) have proven that there is a significant influence between familiarity with employee performance.

c. The results of hypothesis testing (3) have proven that there is a significant influence between management interactions with employee performance.

d. The results of hypothesis testing (4) have proven that there is a significant effect between the power of expression and employee performance.

e. The results of hypothesis testing (5) have proven that there is a significant influence between orientation on others and employee performance. 
f. The results of hypothesis testing (6) have proven that there is a jointly significant influence between selfconfidence, familiarity, management interaction, power of expression, orientation on others with employee performance.

\section{B. Suggestions}

There are some suggestions submitted as a complement to the result of this research are 1) For future research, research can be done on the service sector and construction with longer research time and the development of proportional research instruments, about self-confidence, familiarity, management interaction, power of expression, orientation to others with employee performance. 2) To see the relationship and the strong influence between independent and dependent variables with intervening variables, it is better to use different test equipment from this study. 3) Development of instruments can be adjusted to the object or sector selected in the next study in order to get maximum results. 4) This research relies solely on primary data and it is recommended that future research combine this data with more reliable secondary data.

\section{REFERENCE}

[1] DeVito, J. (2016). Communication Between Humans (Edition 5). Tangerang: Karisma Publishing Group.

[2] Aziz. (2017). Pengaruh Komunikasi Interpersonal Guru terhadap Motivasi Berprestasi dalam Mewujudkan Kinerja Guru. Jurnal Pendidikan Universitas Garut, 11 (01), 9-17

[3] Parastika. (2017). Konstribusi Komunikasi Interpersoanal terhadap Kinerja Guru Sekolah Dasar Negeri Se-Kecamatan Bantul. 1-8. Pemberdayaan SDM". UB Press: Malang.

[4] Pengertian kinerja menurut para ahli. Retrieved February 21, 2019, from https://www.coursehero.com/file/p1 cookr/Dilihat-dari-sudutpandang-ahli-yang-lain-kinerja-adalah-banyaknya-upaya-yang/

[5] Komunikasi Interpersonal masyarakat dalam mengelola wisata Retrieved February 21, 2019, from :http://digilib.uinsby.ac.id/16460/4/Bab\%202.pdf 